BAKTIMAS

Jurnal Pengabdian pada Masyarakat
Vol. 1, No. 2,

Agustus 2019
eISSN 2685-113x

pISSN 2685-0303

\title{
Program Kemitraan Masyarakat melalui Pemanfaatan Alat Peraga untuk Menanggulangi Fobia Matematika pada Sekolah Dasar
}

\author{
Husnidar $^{1}$, Rahmi Hayati ${ }^{2 *}$, Tuti Liana ${ }^{3}$ \\ ${ }^{1,2,3}$ Dosen Universitas Almuslim \\ *Email korespondensi: hayatirahmi@yahoo.com
}

\begin{abstract}
Abstrak
Kurangnya pemahaman guru tentang pentingnya alat peraga untuk menanggulangi fobia matematika menyebabkan pembelajaran di kelas berlangsung satu arah. Hal ini menyebabkan siswa tidak bersemangat belajar dan cenderung benci terhadap matematika. Rasa benci tersebut lama-kelamaan dapat berubah menjadi trauma belajar matematika yang pada umumnya disebabkan oleh pengalaman yang menyakitkan, menakutkan yang bisa saja bersumber dari cara guru mengajar matematika yang selalu bersifat paksaan dan tekanan, seringnya diberikan hukuman oleh sang guru, atau bisa jadi ejekan dari teman sekelasnya. Cara mengajar guru yang menyebabkan siswa trauma diantaranya, guru terbiasa menyuruh siswa mengerjakan soal matematika ke depan kelas dan memberi hukuman ketika siswa tidak mampu, guru selalu memperbanyak pekerjaan rumah dan memberi hukuman apabila siswa lupa mengerjakan tugas. Adapun tujuan dari PKM ini adalah menambah wawasan guru tentang pentingnya cara mengajar matematika yang baik, pendekatan dan motivasi yang baik untuk siswa dan penggunaan alat peraga matematika sehingga dapat menanggulangi fobia matematika. Kegiatan PKM ini telah dilaksanakan di Sekolah Dasar Negeri 4 Bireuen dengan uraian kegiatan penyuluhan dan sosialisasi pentingnya penggunaan alat peraga matematika, pelatihan pembuatan alat peraga serta evaluasi dan monitoring setelah kegiatan PKM berlangsung. Luaran yang diharapkan dari kegiatan ini adalah harapan akan bertambahnya kemampuan dan wawasan guru dalam mengajar matematika, mengelola kelas dengan baik, memotivasi siswa dan menggunakan alat peraga matematika secara optimal.

Kata Kunci : Fobia, Alat Peraga
\end{abstract}

\section{PENDAHULUAN}

Pendidikan merupakan hal yang sangat penting dalam kehidupan karena merupakan alat yang membantu kita untuk memupuk masa depan, memberi pengetahuan, mengajarkan sopan santun, dan bahkan menjadikan kita individu yang dewasa. Selain itu pendidikan juga penting dalam mewujudkan kemajuan kehidupan bangsa, karena ditangan orang-orang berpendidikan suatu negara akan maju, baik di bidang sosial maupun ekonomi. Bangsa Indonesia merupakan salah satu negara yang sangat menjunjung tinggi pengetahuan dan pendidikan, hal ini terbukti dengan adanya UU No. 20 Tahun 2003 pasal 5 ayat 4 tentang Sistem Pendidikan Nasional 
Husnidar, Rahmi Hayati, Tuti Liana

bahwa semua warga Negara memiliki potensi serta kecerdasan oleh karenanya mereka berhak mendapatkan pendidikan.

Pendidikan nasional berfungsi mengembangkan kemampuan dan membentuk watak serta peradaban bangsa yang bermartabat dalam rangka mencerdaskan kehidupan bangsa, bertujuan untuk berkembangnya potensi peserta didik agar menjadi manusia yang beriman dan bertakwa kepada Tuhan Yang Maha Esa, berakhlak mulia, sehat, berilmu, cakap, kreatif, dan menjadi warga negara yang demokratis dan bertanggung jawab. Pendidikan berfungsi untuk menbentuk perilaku dan watak pada peserta didik agar kelak dapat meyesuaikan diri dengan lingkungan.

Sekolah merupakan tempat kedua bagi seorang anak untuk memperoleh pendidikan serta meningkatkan kecerdasan dan ketrampilan. Di sekolah mereka menerima ilmu pengetahuan dan mengenal lingkungan dan belajar tentang tata cara bertanggung jawab terhadap dirinya, terhadap orang lain bahkan terhadap lingkungan sekitarnya.Selain itu sekolah menjadi tempat untuk menyesuaikan diri dalam tantangan hidup dan masa depan serta menjadi pilihan untuk memperbaiki taraf kehidupan, karena di sekolah kita memperoleh berbagai bimbingan dan menghindarkan kita dari buta huruf dan gaptek. Menurut Yusuf (2011: 30) "Sekolah merupakan sebuah lembaga pendidikan formal yang secara sistematis melaksanakan program bimbingan, pengajaran, dan/atau pelatihan dalam rangka membantu para siswa agar mampu mengembangkan potensinya secara optimal, baik yang menyangkut aspek moral-spritual, intelektual, emosional, sosial, maupunfisik- motoriknya".

Sekolah menjadi tempat bagi setiap generasi untuk dapat mengembangkan wawasan dan memiliki karakter. Dalam karakter mengajarkan anak norma agama, serta norma kesopanan, sehingga menjadi berguna bagi agama, nusa dan bangsa. Menurut Sabdulloh (2010: 196) "sekolah merupakan lingkungan pendidikan yang secara sengaja dirancang dan dilaksanakan dengan aturan-aturan yang ketat seperti harus berjenjang dan berkesinambungan, sehingga disebut pendidikan formal, dan sekolah adalah lembaga khusus, suatu wahana, suatu tempat untuk menyelenggarakan pendidikan yang di dalamnya terdapat suatu proses belajar mengajar untuk mencapai tujuan pendidikan tertentu.

Jenjang pendidikan formal paling rendah di Indonesia adalah Sekolah Dasar. Hal ini sesuai dengan UU nomor 20 tentang sistem pendidikan nasional yang menyebutkan bahwa jenjang pendidikan formal di Indonesia terdiri dari pendidikan dasar, pendidikan menengah, dan pendidikan tinggi. Pendidikan dasar ini akan menjadi acuan keberhasilan anak untuk menuju jenjang selanjutnya. Menurut Muhammad Ali (2009: 33)

"Ada 2 fungsi utama pendidikan dasar yaitu: 1) melalui pendidikan dasar peserta didik dibekali kemampuan dasar yang terkait dengan kemampuan berpikir kritis, membaca, menulis, berhitung, penguasaan dasar-dasar untuk mempelajari sainstek, dan kemampuan berkomunikasi yang merupakan tuntutan kemampuan minimal dalam kehidupan bermasyarakat. 2) pendidikan dasar memberikan dasar-dasar untuk mengikuti pendidikan pada jenjang pendidikan berikutnya. Keberhasilan mengikuti pendidikan sekolah menengah 
BAKTIMAS

Jurnal Pengabdian pada Masyarakat
Vol. 1, No. 2,

Agustus 2019
eISSN 2685-113x

pISSN 2685-0303

dan perguruan tinggi banyak dipengaruhi oleh keberhasilan dalam mengikuti pendidikan dasar."

Semakin bagus pola pendidikan dasar pada seorang anak, akan semakin besar peluang keberhasilan pada jenjang selanjutnya. Artinya kesuksesan anak tergantung dari seberapa besar sianak memperoleh pendidikan di sekolah dasar. Untuk itu perlu kepedulian khusus untuk mengawasi dan membimbing anak dimasa sekolah dasar. Kepedulian khusus tersebut yang paling utama didapatkan dari orang tua anak, dimana yang mereka dapatkan dari rumah sampai pada saat mereka bermain di luar rumah. Kepedulian khusus yang paling besar kedua setelah orang tua adalah di sekolah yaitu dari guru-guru dan kepala sekolah tempat mereka memperoleh pendidikan. Berdasarkan hal tersebut di sekolah diperlukan guru-guru yang bukan hanya pintar mengajar, tetapi juga guru-guru yang mau peduli terhadap permasalahan sianak dan peka terhadap apapun yang berhubungan dengan perkembangan anak.

Salah satu pelajaran penting di sekolah dasar yang membutuhkan dedikasi khusus dalam mengajarkan kepada siswa adalah pelajaran matematika. Mengingat masih banyak siswa yang beranggapan bahwa matematika merupakan mata pelajaran yang menakutkan dan sukar dipelajari, maka disini dibutuhkan bentuk kepedulian khusus dari guru terhadap anak didik dengan terus mencari solusi yang terbaik ketika mereka mendapat ganjalan dalam pelajaran tersebut. Matematika bukan sekedar pelajaran tentang penjumlahan, pengurangan, perkalian dan pembagian, tetapi matematika harus dapat diaplikasikan dalam kehidupan sehari-hari, melalui perpainan agar lebih dicintai oleh peserta didik. Apalagi matematika pada jenjang Sekolah Dasar yang menjadi penentu untuk penguasaan matematika pada jenjang selanjutnya yang lebih tinggi. Jika pada Sekolah Dasar anak menerima banyak tekanan atau apapun hal-hal yang menakutkan ketika belajar matematika maka jangan heran jika sampai kapanpun anak akan fobia terhadap matematika.

Fobia atau fobi adalah suatu ketakutan yang tidak masuk akal namun penderita dapat menjelaskan apa penyebab dan bagaimana cara mengatasi ketakutannya itu (Elida Prayitno, 2009:13). Suatu hal yang menurut kita wajar bisa saja mengerikan bagi mereka yang fobia terhadap sesuatu. Demikian juga fobia matematika adalah rasa takut yang berlebihan terhadap pelajaran matematika yang disebabkan oleh banyak hal yang pernah dirasakan ketika mereka mempelajari matematika. Penyebab tersebut bisa berasal dari gurunya atau bahkan dari kawannya. Menurut Bagby dan Shafer (dalam Elida Prayitno 2009:14) mengemukakan bahwa: "Penyebab penderitaan fobia yaitu :1) Pengalaman yang menyakitkan atau menakutkan akan menimbulkan pengalaman traumatik. Pengalaman yang sangat menyakitkan atau menakutkan yang menimbulkan trauma itu, biasanya dialami pada masa kanak-kanak. Misalnya pengalaman traumatik yang berkaitan dengan hal-hal yang memalukan atau peristiwa yang terlarang. Oleh karena itu penderita menghindari pikiran atau ingatan berkenaan dengan peristiwa yang sangat memalukan itu dan tidak ingin diketahui oleh orang lain. Pikiran atau ingatan yang memlaukan itu disingkirkan oleh penderita dari kesadarannya dengan menekannya kealam bawah sadarnya, sehingga dia lupa. 2) fobia muncul karena perasaan bersalah atau berdosa yang sangat tinggi. Situasi yang memalukan dicegah agar situasi itu tidak muncul dlam kesadaran. Namun ketakutan atau fobia tidak akan muncul jika 
Husnidar, Rahmi Hayati, Tuti Liana

penderita memiliki memiliki hubungan yang harmonis, bahagia, aman dan damai dengan orang tua semasa kanak-kanak dan setelah berkeluarga dan menikah. 3) fobia terhadap objek tertentu dapat menyebabkan pobia terhadap objek lain. Dengan kata lain fobia dapat merembet kepada ketakutan kepada objek lainya. 4) Selain itu salah satu penyebab fobia adalah Imajinasi yang berlebihan dapat juga menyebabkan phobia."

Fobia matematika umumnya disebabkan oleh pengalaman yang menyakitkan, menakutkan dan pengalaman traumatik. Penyebab traumatik disini bisa bersumber dari guru yang mengajar matematika, atau bisa jadi dari teman sekolahnya. Cara mengajar guru yang menyebabkan siswa trauma diantaranya, guru terbiasa menyuruh siswa mengerjakan soal matematika ke depan kelas dan memberi hukuman ketika siswa tidak mampu, guru selalu memperbanyak pekerjaan rumah dan memberi hukuman apabila siswa lupa mengerjakannya atau siswa salah mengerjakannya, atau guru mengajar dengan model itu-itu saja tanpa menggunakan alat peraga yang bisa menarik minat belajar siswa. Sedangkan trauma dari kawan siswa misalnya ketika siswa tidak mampu mengerjakan soal dipermalukan oleh teman sekelasnya. Hal-hal seperti ini dapat mengakibatkan siswa membenci pelajaran matematika bahkan tidak mau mengenal matematika.

Upaya yang dapat dilakukan guru agar pelajaran matematika itu lebih disenangi dan tidak menakutkan bagi siswa adalah berusaha menggunakan alat-alat peraga yang sesuai dengan materi pelajaran dan mudah diingat oleh siswa, dan yang paling penting diajarkan dengan penuh kasih sayang tanpa adanya paksaan dengan banyak hafalan atau PR. Alat paraga matematika dapat digunakan untuk menanamkan konsep-konsep matematika, dapat dimanipulasi, dikutak-katik sehingga menarik dan menyenangkan bagi anak-anak.

Alat peraga matematika dipergunakan sesuai dengan fungsi dan kebutuhannya dan disesuaikan dengan waktu yang tersedia. Menurut (Siti Annisah, 2014) menyatakan bahwa: "fungsi alat peraga khususnya media visual adalah, 1) fungsi atensi, yaitu media visual inti artinya menarik dan mengarahkan siswa untuk berkonsentrasi pada isi pelajaran. Seringkali pada awal pelajaran siswa tidak tertarik dengan materi pelajaran yang tidak disenangi sehingga mereka tidak memperhatikan. 2) fungsi afektif, media dapat terlihat dari tingkat kenikmatan siswa ketika belajar atau membaca teks yang bergambar. Gambar atau lambang visual dapat mengubah emosi dan sikap siswa, misalnya informasi menyangkut masalah solial. 3) fungsi kognitif, media dapat terlihat dari temuan-temuan penelitian yang menggunakan lambang visual atau gambar memperlancar pencapaian informasi atau pesan yang terkandung dalam gambar. 4) fungsi kompensatoris, media pembelajaran terlihat dari hasil penelitian bahwa media yang memberikan konteks untuk memahami teks membantu siswa yang lemah dalam membaca atau mengorganisasikan informasi dalam teks dan mengingatnya kembali."

Sementara menurut hasil observasi, di sekolah Dasar Negeri 4, masih banyak siswa yang kurang suka belajar matematika dan menganggap matematika sebagai mata pelajaran yang membosankan. Sedangkan guru-guru di SD tersebut masih kurang peduli terhadap permasalahan siswanya, dan masih guru yang mengajar secara tradisional tanpa bantuan alat peraga. Berdasarkan hasil analisis situasi tersebut tim 
BAKTIMAS

Jurnal Pengabdian pada Masyarakat
Vol. 1, No. 2,

Agustus 2019
eISSN 2685-113x

pISSN 2685-0303

PKM Universitas Almuslim telah mengadakan kegiatan "Program kemitraan masyarakat melalui pemanfaatan alat peraga untuk menanggulangi fobia matematika pada sekolah dasar."

\section{TUJUAN}

Tujuan dari Program Kemitraan Masyarakat ini adalah untuk menambah wawasan guru matematika tentang pentingnya cara mengajar matematika yang baik, pendekatan dan motivasi yang baik untuk siswa dan penggunaan alat peraga matematika sehingga dapat menanggulangi fobia matematika.

\section{METODE}

Metode pendekatan yang diterapkan dalam PKM ini adalah terdiri dari 3 kegiatan pengabdian yaitu sosialisasi dan penyuluhan, pendampingan dan pelatihan, serta evaluasi dan monitoring. Dalam kegiatan penyuluhan ini guru diberikan pengetahuan oleh tim PKM tentang pentingnya menanggulangi fobia terhadap matematika di Sekolah Dasar Negeri 4 dengan memaksimalkan penggunaan alat peraga matematika. Metode yang ditawarkan untuk menyelesaikan permasalahan fobia matematika ini adalah melalui pembinaan guru dan siswa, pelatihan pembuatan alat peraga matematika pada guru dan cara menggunakan alat peraga pada guru dan siswa. Sedangkan pendampingan dan pelatihan dilaksanakan pada saat pembuatan alat peraga matematika, saat guru mengajar matematika dan juga saat pelatihan penggunaan alat peraga sesuai dengan waktu yang telah disepakati. Evaluasi dan monitoring direncanakan terus dilaksanakan sampai pengabdian ini selesai dan memberikan hasil yang memuaskan.

\section{HASIL DAN PEMBAHASAN}

Berikut ini adalah beberapa kegiatan PKM (Program Kemitraan Msyarakat) yang telah dilaksanakan oleh tim PKM Umuslim yaitu sosialisasi pentingnya pencegahan fobia matematika, dimana menurut pengalaman guru di SD N 4 mereka juga selalu menemukan siswa - siswa yang tidak senang belajar matematika. Pada umumnya mereka enggan mendengar penjelasan dari guru. Guru di sana tidak menyadari bahwa anak didik nya telah mengalami fobia terhadap matematika. Setelah kegiatan ini mereka merencanakan akan berusaha mengadakan pendekatan terhadap siswa tersebut.

Selanjutnya pada sosialisasi juga dibahas pentingnya pemanfaatan alat peraga dalam pembelajaran matematika, agar siswa tidak bosan dan mudah mengingat pelajaran matematika. Menurut guru matematika yang ikut dalam kegiatan tersebut selama ini mereka telah mulai menggunakan alat peraga matematika, tetapi belum maksimal. Untuk memaksimalkan hal tersebut kami telah melaksanakan pelatihan pembuatan alat peraga matematika, serta pendampingan pembuatan alat peraga dan aplikasinya dalam pembelajaran di Sekolah Dasar Negeri 4 Bireuen. Berdasarkan hasil sosialisasi dan kegiatan pelatihan, guru-guru dan kepala sekolah sangat antusias 
menanggapi kegiatan tersebut. Selain itu guru berusaha memahami cara pembuatan alat peraga matematika serta cara menggunakannya baik yang langsung dijelaskan oleh tim PKM maupun dari pemutaran Video. Hasil tersebut merupakan serangkaian luaran yang telah dicapai sesuai dengan perencanaan.
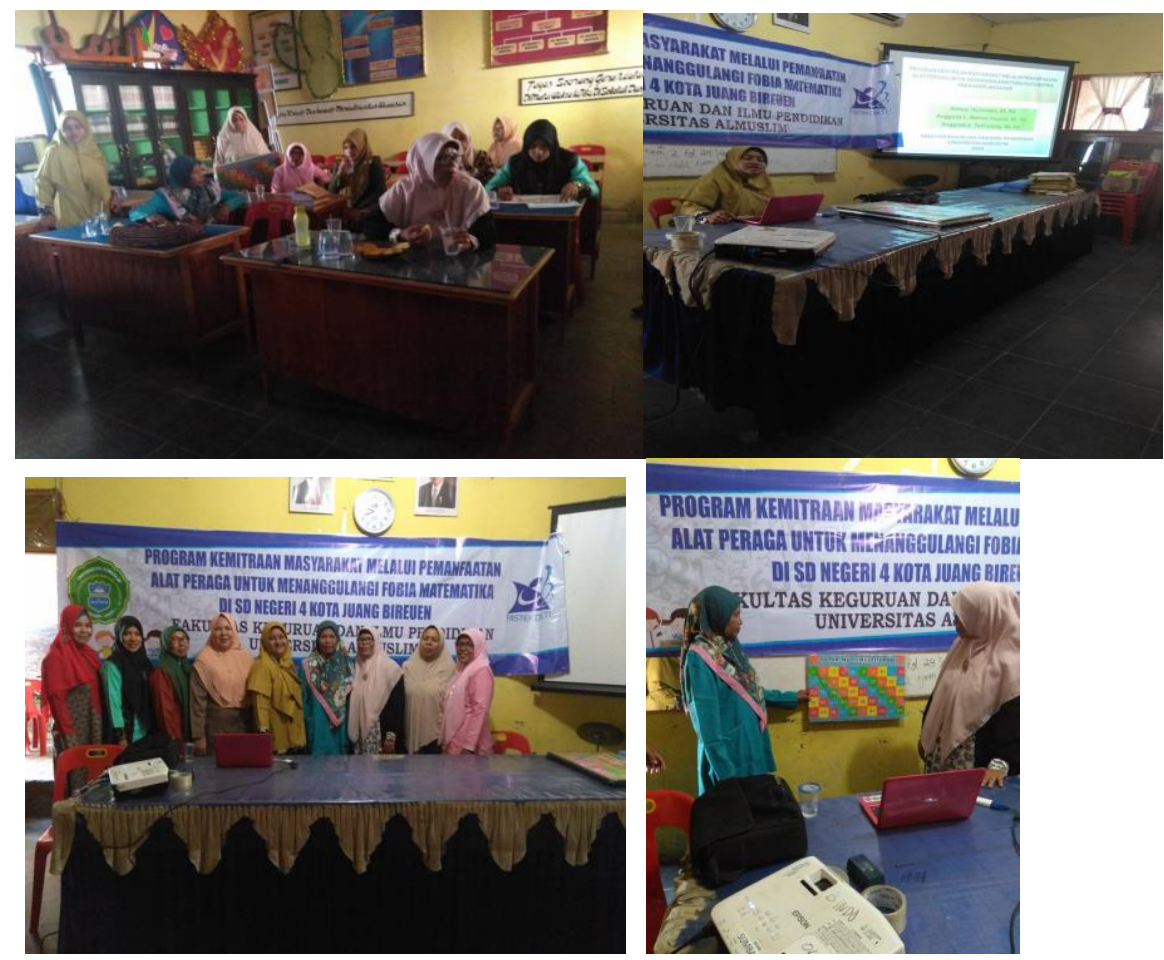

Gambar 1. Foto Kegiatan Penggunaan alat Peraga untuk mengantisipasi Fobia Matematika

\section{PENUTUP}

Sosialisasi Fobia matematika merupakan serangkaian pengenalan kepada guruguru SD tentang adanya sebagian siswa yang trauma terhadap matematika serta cara menanggulanginya. Salah satu cara menanggulangi fobia tersebut adalah dengan penggunaan alat peraga dalam pembelajaran matematika. Dengan adanya kegiatan tersebut diharapkan dapat menginspirasi guru-guru di SD N 4 agar lebih inovatif dalam mengelola pembelajaran.

\section{DAFTAR PUSTAKA}

Annisah, S. 2014. Alat Peraga Pembelajaran Matematika. Jurnal Tarbawiyah. Volume 11 Nomor 1, Edisi Januari-Juli

Ali, Mohammad. 2009. Pendidikan untuk Pembangunan Nasional: Menuju Bangsa Indonesia yang Mandiri dan Berdaya Saing Tinggi. Bandung: INTIMA. 
BAKTIMAS

Jurnal Pengabdian pada Masyarakat
Vol. 1, No. 2,

Agustus 2019
eISSN 2685-113x

pISSN 2685-0303

Elida Prayitno. 2009. Psikologi Abnormal. Padang; FIP UNP

Sabdulloh, U. 2010. Pedagogik Ilmu Mendidik. Bandung.Alfabeta.

Yusuf, Syamsu. 2011. Peserta Didik. Jakarta: PT Raja Grafindo persada. 